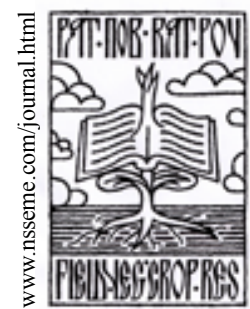

\title{
Gene Effects and Combining Abilities for Oil Content in Sunflower
}

\author{
Milan Jocković • Slaven Prodanović • Siniša Jocić • Radovan Marinković • \\ Ana Marjanović Jeromela • Bojan Jocković • Petar Čanak
}

\author{
received: 17 July 2014, accepted: 24 September 2014 \\ published online: 6 October 2014 \\ (c) 2014 IFVC \\ doi: $10.5937 /$ ratpov51-6464
}

\begin{abstract}
Summary: Considering the worldwide importance of sunflower oil, objective of this study was to evaluate gene effects and combining abilities of six sunflower open pollinated varieties. Varieties were crossed according to incomplete diallel method and produced fifteen F1 progenies. Comparing the mean values of $\mathrm{F} 1$ progenies to parents mean in most cases superdominance was expressed as a mode of inheritance. Nonetheless, dominance of better parent and partial dominance of better parent were also recorded as a mode of inheritance. GCA/SCA ratio indicated greater importance of non-additive genetic component in oil content expression. The genetic variance analysis showed that dominant component was more important and dominant genes prevailed compared to recessive genes for oil content in sunflower.

Keywords: combining abilities, gene effects, inheritance, oil content, sunflower, variety
\end{abstract}

\section{Introduction}

Sunflower (Helianthus annuus L.) is one of the most important oilseed crops in the world and the preferred source of oil for salads and cooking (Hu et al. 2010). Sunflower oil is a valuable source of tocopherols and phytosterols and has positive effect on human health (Bramley et al. 2000, Patel \& Thompson 2006, Gotar et al. 2008). It has a relatively high concentration of linoleic acid which is an essential poly-unsaturated fatty acid that is not synthesized by humans and is a precursor of gammalinolenic acid and arachidonic acid (Dorell 1978). Sunflower oil has a wide range of applications and can be used as a supplement in chemical industry in production of varnishes, copolymers, polyester films, modified resin, plasticizer and detergent, as well as in pharmaceutical industry.

Oil content is a quantitative trait and it is very variable depending on the genetic background and environmental conditions. Success in breeding

M. Jocković* • S. Jocić • R. Marinković • A. Marjanović-Jeromela • B. Jocković $\bullet$ P. Čanak

Institute of Field and Vegetable Crops, 30 Maksima Gorkog, 21000 Novi Sad, Serbia

S. Prodanović

University of Belgrade, Faculty of Agriculture, Nemanjina 6, 11080 Zemun-Belgrade, Serbia largely depends on genetic variability in the initial material. Thorough knowledge of the mode of inheritance and combining ability in the material which is available has a crucial role in the breeding process with the goal of creating superior genotypes that can bring progress in production. Plant breeders frequently use diallel analysis to evaluate general combining abilities (GCA) of parents and specific combining abilities (SCA) of their crosses for a number of traits. Investigation on gene effect for oil content in sunflower so far provided different results depending on the genetic divergence in studied material. In previous studies Škorić (1976), Miller et al. (1980) and Marinković (1984) reported additive gene effect, while investigations of Marinković (1993) and Škorić et al. (2000) reported that non-additive genes were responsible for oil content in sunflower.

Present investigation was performed to obtain information about gene effects and combining abilities of sunflower open pollinated varieties and their $F_{1}$ progeny for oil content.

\footnotetext{
Acknowledgements:

This study is part of the research project no. TR-31025 titled "Development of new varieties and production technology improvement of oil crops for different purposes" financed by the Ministry of Education, Science and Technological Development of the Republic of Serbia.
} 


\section{Materials and Methods}

This study included six sunflower varieties crossed according to diallel method, without reciprocals. Parental lines and their fifteen $F_{1}$ hybrids were sown in three replicates at the experimental field Rimski Šančevi of the Institute of Field and Vegetable Crops, Novi Sad. Basic plots were $10 \mathrm{~m}^{2}$, with four $3.6 \mathrm{~m}$ long rows and $70 \times 30 \mathrm{~cm}$ plant spacing. The data were recorded on 10 plants in each replicate from middle rows. Oil content was determined by nuclear magnetic resonance (NMR) in pure seed and expressed in percentage. Mode of inheritance was determined by applying test of significance ( $\mathrm{t}$-test) of the mean values of $F_{1}$ progenies compared to parents' means. General combining abilities (GCA) and specific combining abilities (SCA) were tested using diallel method (Griffing 1956), while analysis of components of genetic variance was performed according to the method suggested by Mather and Jinks (1971).

\section{Results and Discussion}

Comparing the mean values of oil content between parents and $F_{1}$ progeny it is evident that in most cases superdominance $\left(\mathrm{sd}^{+}\right)$, i.e. heterosis, was expressed as a mode of inheritance (Tab. 1). Dominance of better parent $\left(\mathrm{d}^{+}\right)$was expressed five times and partial dominance of better parent $\left(\mathrm{pd}^{+}\right)$in one crossing combination as a mode of inheritance for oil content. In earlier study Škorić (1975) reported heterotic effects for the inheritance of sunflower oil content.

As GCA and SCA provide information for additive and non-additive gene actions, respectively (Sprague \& Tatum 1942), analysis of variance for combining ability of oil content in sunflower

Table 1. Mean values, mode of inheritance, standard deviation and coefficient of variation for oil content (\%) in sunflower

\begin{tabular}{|c|c|c|c|}
\hline Genotype & $\mathrm{X}$ & $\mathrm{SD}+$ & $\mathrm{V}(\%)$ \\
\hline$S 1$ & 44.35 & 3.69 & 8,32 \\
\hline S2 & 45.43 & 3.90 & 8,59 \\
\hline S3 & 46.11 & 3.71 & 8,05 \\
\hline S4 & 49.78 & 3.21 & 6,45 \\
\hline S5 & 49.17 & 4.14 & 8,42 \\
\hline S6 & 45.41 & 3.72 & 8,19 \\
\hline S1xS2 & $50.37^{\text {sdt }}$ & 2.99 & 5,94 \\
\hline S1xS3 & $51.38^{\text {sd } t}$ & 2.74 & 5,34 \\
\hline S1xS4 & $49.47^{\mathrm{d}+}$ & 3.67 & 7,43 \\
\hline S1xS5 & $51.87^{\mathrm{sd}+}$ & 3.68 & 7,09 \\
\hline S1xS6 & $50.41^{\text {sd }+}$ & 4.27 & 8,48 \\
\hline$S 2 \times S 3$ & $49.83^{\text {sdt }}$ & 3.76 & 7,54 \\
\hline S2xS4 & $49.35^{\mathrm{d}+}$ & 2.98 & 6,04 \\
\hline S2xS5 & $48.25^{\mathrm{pd}+}$ & 5.85 & 12,12 \\
\hline $52 \times 56$ & $48.84^{\mathrm{sd}+}$ & 3.19 & 6,53 \\
\hline S3xS4 & $50.79^{\mathrm{d}+}$ & 3.46 & 6,81 \\
\hline S3xS5 & $50.77^{\mathrm{d}+}$ & 3.15 & 6,21 \\
\hline S3xS6 & $52.00^{\mathrm{sd} t}$ & 2.43 & 4,67 \\
\hline S4xS5 & $53.13^{\mathrm{sd}+}$ & 3.22 & 6,06 \\
\hline $54 \mathrm{x} 56$ & $51.74^{\mathrm{d}+}$ & 2.81 & 5,43 \\
\hline $55 \times S 6$ & $51.94^{\mathrm{sd}+}$ & 1.61 & 3,09 \\
\hline LSD (5\%) & 2.54 & & \\
\hline LSD (1\%) & 3.41 & & \\
\hline
\end{tabular}

sd - superdominance; $\mathrm{d}^{+}$- dominance of better parent; $\mathrm{pd}^{+}$- partial dominance of better parent 
Table 2. Analysis of variance for combining ability of oil content in sunflower

\begin{tabular}{lcccccc}
\hline \multicolumn{1}{c}{ Source } & Df & SS & MS & F & F $(0,05)$ & $F(0,01)$ \\
\hline GCA & 5 & 27.61 & 5.52 & $7.01^{* *}$ & 2.45 & 3.51 \\
SCA & 15 & 90.41 & 6.03 & $7.65^{* *}$ & 1.94 & 2.55 \\
Error & 40 & 31.51 & 0.79 & & & \\
\hline
\end{tabular}

Table 3. General (bold) and specific combining ability for oil content on sunflower

\begin{tabular}{lcccccc}
\hline Parents & S1 & S2 & S3 & S4 & S5 & S6 \\
\hline S1 & -0.57 & $2.60^{*}$ & $2.37^{*}$ & -0.39 & 1.96 & 1.57 \\
S2 & & -1.19 & 1.41 & -0.08 & -1.04 & 0.62 \\
S3 & & 0.04 & 0.32 & 0.25 & $2.55^{*}$ \\
S4 & & & 0.89 & 1.76 & 1.43 \\
S5 & & & & $0.95^{*}$ & 1.58 \\
S6 & & & & & -0.12 \\
\hline
\end{tabular}

indicated that additive and non-additive genetic components were important in the inheritance of oil content as presented by GCA and SCA values (Tab. 2). The GCA/SCA ratio was lower than 1, meaning that non-additive component was more important than additive. In agreement with this study Parameswari et al. (2004) and Hladni et al. (2006) also reported prevalence of non-additive genetic component for oil content. Nonetheless, investigations of Ortegon-Morales et al. (1992), Rojas and Fernandez-Martinez (1998) and Mijić et al. (2008) reported higher importance of additive component.

Analysis of GCA and SCA effects showed that there were significant differences among parents and crosses for oil content in sunflower (Tab. 3). Significant and positive GCA effect was only recorded for variety $\mathrm{S} 5$ which makesit thebestgeneralcombinerforimproving oil content. Positive GCA effect was recorded also for varieties $S 3$ and $S 4$ but without significance. Varieties S1, S2 and S6 had negative GCA effect for oil content. SCA effects for oil content were found positive and significant in crosses $S 1 \times \mathrm{xS} 2, \mathrm{~S} 1 \mathrm{xS} 3$ and $\mathrm{S} 3 \mathrm{xS6}$, while in crosses $\mathrm{S} 1 \mathrm{xS} 4, \mathrm{~S} 2 \mathrm{xS} 4$ and $\mathrm{S} 2 \mathrm{xS} 5 \mathrm{SCA}$ effects were negative (Tab. 3).

The analysis of the components of genetic variance indicated that dominant component $\left(\mathrm{H}_{1}\right.$ and $\mathrm{H}_{2}$ ) was larger than additive (D) in oil content expression (Tab. 4). According to $F$ value, which is positive, dominant genes prevailed compared to recessive ones in the inheritance of oil content. This is in agreement with the frequency of dominant $(\mathrm{u})$ and recessive $(\mathrm{v})$ genes and $\mathrm{K}_{\mathrm{D}} / \mathrm{K}_{\mathrm{R}}$ ratio which is larger than 1 and represent the total number of dominant versus recessive genes. Dominant and recessive genes were not equally distributed among parents as confirmed by the $\mathrm{H}_{2} / 4 \mathrm{H}_{1}$ ratio. Moreover, average degree of dominance $\left(\sqrt{ } \mathrm{H}_{1} / \mathrm{D}\right)$ indicated that seed oil content exhibited superdominance in the $F_{1}$ generation, considering all crossings (Tab. 4).

Table 4. Components of genetic variance for oil content in sunflower

\begin{tabular}{cc}
\hline Component & Value \\
\hline $\mathrm{D}$ & 4.17 \\
$\mathrm{H}_{1}$ & 15.64 \\
$\mathrm{H}_{2}$ & 14.02 \\
$\mathrm{~F}$ & 3.49 \\
$\mathrm{E}$ & 0.79 \\
$\mathrm{u}$ & 0.66 \\
$\mathrm{v}$ & 0.34 \\
$\mathrm{H}_{2} / 4 \mathrm{H}_{1}$ & 0.22 \\
$\sqrt{ } \mathrm{H}_{1} / \mathrm{D}$ & 1.94 \\
$\mathrm{~K}_{\mathrm{D}} / \mathrm{K}_{\mathrm{R}}$ & 1.55 \\
\hline
\end{tabular}

\section{Conclusions}

Development of superior synthetics or hybrids involves estimation of gene action in various traits in order to design an efficient breeding plan for further genetic improvement of the initial material. Sunflower oil content is one of the most important 
traits considering this crop and information about inheritance, gene effects and combining abilities are necessary for improving this valuable trait.

According to results from this study, superdominance prevailed as a mode of inheritance for sunflower oil content. The non-additive genetic component was more important than additive in the expression of oil content. The best general combiner for oil content is variety $S 5$ because of the highest GCA effect, while the highest significant positive SCA effects were recorded in crosses S1xS2, S1xS3 and S3xS6. Dominant genes were predominant compared to recessive ones, which was confirmed with the frequencies of dominant and recessive genes.

\section{References}

Bramley, P.M., Elmafda, I., Kafatos, A., Kelly, F.., Manios, Y., Roxborough, H.E., ... Wagner, K.H. (2000). Vitamin E. Journal of the Science of Food and Agriculture, 80(7), 913-938.

Dorrell, D.G. (1978). Processing and utilization of oilseed sunflower. In J.F. Carter (Ed.), Sunflower Science and Technology. (pp. 407-436). Madison, WI., USA: Crop Science Society of America.

Gotar, A.A., Berger, M., Labalette, F., Centis, S., Dayde, J., \& Calmon, A. (2008). Estimation of breeding potential for tocopherols and phytosterols in sunflower. In: Proc. of the 17th International Sunflower Conference, Cordoba, Spain. 555-559.

Griffing, B. (1956). Concept of general and specific combining ability in relation to diallel crossing systems. Australian Journ. Biol. Sci., 9, 463-496.

Hladni, N., Škorić, D., Kraljević-Balalić, M., Sakač, Z., \& Jovanović, D. (2006). Combining ability for oil content and its correlations with other yield components in sunflower. Helia, 29(44), 101-110. doi:10.2298/HEL0644101H

Hu, J., Seiler, G., \& Kole, C. (2010). Genetics, genomics and breeding of sunflower. (p. 342). USA: Routledge.
Marinković, R. (1984). Mode of inheritance of seed yield and some yield components in crossings of various inbred sunflower lines. Doctoral dissertation. Novi Sad: University of Novi Sad, Faculty of Agriculture. (In Serbian).

Marinković, R. (1993). Components of genetic variability for characters affecting oil yield of sunflower (Helianthus annuus L.). J. Genet. \& Breed, 47, 289-291.

Mather, K., \& Jinks, J.L. (1971). Biometrical genetics. (pp. 1-382). London: Chepman and Hall.

Mijić, A., Kozumplik, V., Kovačević, J., Liović, I., Krizmanić, M., Duvnjak, T., ... Gunjača, J. (2008). Combining abilities and gene effects on sunflower grain yield, oil content and oil yield. Periodicum biologorum, 110(3), 277-284.

Miller, J.F., Hammond, J.J., \& Roath, W.W. (1980). Comparison of inbreds vs. Single cross testers and estimation of genetic effects in sunflower. Crop. Sci., 20, 703-706.

Ortegon-Morales, A.S., Escobedo-Mendoza, A., \& Quilantan-Villarreal, L. (1992). Combining ability of sunflower (Helianthus annuus $\mathrm{L}$.) lines and comparison among parent lines and hybrids. In: Proc. of the 13th Inter. Sunf. Conf. Pisa, Italy. 1178-1193.

Parameswari, C., Muralidharan, V., Subbalakshmi, B., \& Manivannam, N. (2004). Genetic analysis yield and inportant traits in sunflower (Helianthus annuus L.). Hybrids. Journal of Oil seed Research, 21(1), 168-170.

Patel, M.D., \& Thompson, P.D. (2006). Phytosterols and vascular disease. Atherosclerosis, 186(1), 12-9. pmid:16325823

Rojas, P., \& Fernández-Martínez, J.M. (1998). Combining ability of oil and protein among six sunflower lines. In: Proc. of the EUCARPIA-International Symposium on Breeding of Protein and Oil Crops, Pontevedra, Spain. 1-4.

Sprague, G.F., \& Tatum, L.A. (1942). General vs. specific combining ability in single crosses of corn. Journ. Amer. Soc. Agr, 34, 923-932.

Škorić, D. (1975). Possibility of using heterosis based on male sterility in sunflower. Doctoral dissertation. Novi Sad: University of Novi Sad, Faculty of Agriculture. (In Serbian).

Škorić, D. (1976). Mode of inheritance of oil content in sunflower seed of F1 generation and components of genetic variability. In: Proc of the 7th Inter. Sunf. Conf., 27 June-3 July, Krasnodar, SSSR. 376-388.

Škorić, D., Jocić, S., \& Molnar, I. (2000). General (GCA) and specific (SCA) combining abilities in sunflower. In: Proc. of the 15th Int. Sunf. Conf., Toulouse, France. 23-30.

\title{
Efekat gena i kombinacione sposobnosti za sadržaj ulja u suncokretu
}

\author{
Milan Jocković • Slaven Prodanović • Siniša Jocić • Radovan Marinković • \\ Ana Marjanović Jeromela • Bojan Jocković • Petar Čanak
}

\begin{abstract}
Sažetak: Sobzirom na svetski značaj suncokretovog ulja, cilj ovog istraživanja je bio da se procene efekti gena i kombinacione sposobnosti šest sorti suncokreta. Sorte su ukrštene metodom nepotpunog dialela i proizvedeno je petnaest F1 potomstava. Poredeći srednje vrednosti $F 1$ potomstava sa srednjim vrednostima roditelja u većini slučajeva kao način nasleđivanja ispoljila se superdominacija. Pored toga, dominacija boljeg roditelja i parcijalna dominacija boljeg roditelja su takođe zabeležene kao način nasleđivanja. OKS/PKS odnos je ukazao na veći značaj neaditivne genetičke komponente u ekspresiji sadržaja ulja. Analiza genetičke varijanse je pokazala da je dominantna komponenta bila važnija i dominantni geni su preovlađivali u odnosu na recesivne za sadržaj ulja kod suncokreta.

Ključne reči: efekti gena, kombinaciona sposobnost, nasleđivanje, sadržaj ulja, sorta, suncokret
\end{abstract}

